\title{
Implementing Transparency and Participation: An Overview in Public Service
}

\author{
Sitti Mutmainnah Syam ${ }^{1}$, Syamsul Bachri ${ }^{1}$, Andi Pangerang Moenta ${ }^{1}$ \\ ${ }^{1}$ Faculty of Law, Hasanuddin University, Indonesia
}

\begin{abstract}
This research aims to know and explain the application of the principles of good governance, namely the principles of transparency and participation and the constraints of applying the principles of transparency and participation in public services. The research method used is empirical research method, to achieve this goal, so this research uses data collection techniques through interviews, observations, document studies, and documentation. While the data sources used are primary and secondary data sources. The approach of this research is conceptual approach that is moving from the views or doctrines that develop in the science of law and the approach of the Law, namely the approach carried out by edilah regulation related to legal issues that are being studied. The results revealed that the principle of transparency has not run optimally because the SOP has not been informed to the public, the principle of participation has not run optimally because the management of complaints has not been good. Therefore, in the context of public services that are a very strategic part in measuring good governance needs to be optimized by providing SOP information on information boards, websites, brochures, opening complaints through social media or working with village officials, head of Cluster Area to directly socialize public service procedures and policies to the community.
\end{abstract}

Keywords: Good Governance, Public Service, Standard Operating Procedure

Received: December 20, 2020

Revised: December 26, 2020

Accepted: January 2, 2021

\section{Introduction}

Since the era of reform emerged, Indonesia began to present a national and state life order that is more open than the previous era, the democratic order and openness is seen not only in political life but also in other areas of life such as governance.

Changes in the level of knowledge and education of the public are increasingly critical to the improvement of government performance, especially related to the functions and duties of the government (Ilmar, 2014). And Indonesia's governance is more transparent and orientated to the interests of grassroots communities, and good governance is what appears to be the central issue to make this happen.

Governance improvement takes a short time and continuous effort (Novianti, 2015). It can be said that until now after twenty-two years since the reformation began, the effort has not been at the point of success, the existing tradition of governance is far from good governance. There are still many found various prakik administrations that deviate, or bad governance such as the occurrence of various actions or acts of corruption, illegal levies, bribes, and inflating the budget (Ilmar, 2014). We can see from the still lame and less proportional division of roles between the government and non-government institutions, so that the synergy of the two is not optimal, the ability of the government to carry out activities efficiently, fairly, and responsive to the needs of the community is still very limited (Dwiyanto, 2008). These things indicate that we have not succeeded in realizing good governance. 
The practice of good governance has a broad dimension so that there are many aspects that must be intervened, there is not much information available about strategic aspects that need to be prioritized to be focused in improving the performance of the government, while each region has a complexity of different governance problems, as well as commitments and concerns from various stakeholders about different government reforms and in general still low causes us difficulty in realizing good governance (Dwiyanto , 2008).

Renewing the development of good governance practices will be easier to start from the public service reform sector, because the values of good governance such as transparency and participation are relatively easy in the delivery of public services rather than institutionalizing these values in all aspects of government activities (Dwiyanto, 2008).

Therefore, the key to the success of good governance lies in the quality of our public services, so improving the quality of public services is a must, but it is a common awareness that the central government and local governments have not been able to provide quality public services in accordance with the challenges faced. Unhealthy business modes that lead to the practice of KKN (Corruption, Collusion, Nepotism) (Novianti, 2015), service standards that do not include certainty in terms of procedures, costs and time for completion of services are unclear and not yet transparent, and the ineffective public complaint system as a form of community participation in supporting the implementation of public services still pollutes public services.

This condition affects almost all of our public service institutions, including Makassar City. The results of a survey from an independent institution for monitoring public services, the Ombudsman, an institution that has the authority to supervise the implementation of public services organized by state and government administrators as regulated in Law of the Republic of Indonesia Number 37 of 2008, reports that Makassar's public service report cards are still in the yellow zone or moderate level of compliance. This means that compliance has not been maximized in accordance with the application of the rules in the Law. The Ombudsman assesses that the services of the Makassar City Population and Civil Registry Service (Disdukcapil) are still weak in terms of infrastructure, are not transparent and have no certainty of service, facts on the ground show that some, sub-districts and related parties do not know the updated information on online service procedures offered Disdukcapil, not to mention the problem of online services offered through the Disdukcapil website according to the Ombudsman is just a formality.

In addition, there are still complaints from the community regarding the convoluted service procedures of the Makassar City Disdukcapil office, and the length of the service process because the Makassar City Dikdukcapil office is no longer able to accommodate the entire population administration of the Makassar City community where the number to be served is more than the number of servants. The Chairperson of Commission A for Law and Government Affairs during the recess received complaints from the public regarding community services in several government agencies that were deemed not to provide good services. One of them is the Disdukcapil of Makassar City where people have to queue and wait for hours to take care of their population documents.

Disdukcapil (Department of Population and Civil Registration), which is the spearhead of public services and an inseparable part of local governance or regional government, can be one of the doors to assess whether the government has applied the principles of good governance or good governance in service providers that are in direct contact with the community. The cases in the Department of Population and Civil Registry in Makassar City are interesting to study, especially those related to services. All these problems have become the government's homework to date, the government must realize that the future of public 
services is one of the keys to the future of bureaucratic relations. and people with all the desired qualities, the functioning of good public services is the main motor for the presence of the state in the community (Sulaiman et al., 2018). In addition, public services are indicators of the success of Good Governance, if public services are bad, good governance will never be realized.

\section{Methods}

In an effort to obtain data in research, the author uses empirical research methods, namely research that has field data as the main data source, through interviews and observations. Data analysis techniques, namely secondary data and primary data are processed and analyzed using a theoretical basis to answer the problem of the research objectives to be achieved in the research, then presented descriptively, namely the delivery of the results of the analysis by selecting data that describes the actual situation. Explain, describe and describe the problems, and their solutions related to this research.

\section{Results and Discussion}

\section{Application of the Principle of Transparency in Public Services}

Transparency is one of the absolute requirements for realizing good governance, whether good or bad governance, one of which is determined by the level of transparency carried out by the government in providing public services (Bovaird \& Löffler, 2003; Ladwig et al., 2011; Borah, 2013). In serving the community, the government is required to be open to information regarding the public policy process, planning and evaluation of service policies that must be easily accessed by the people who will receive the services. Transparency of costs, requirements, time needed, and methods or procedures for public services to be easily accessed by the public. Transparency has implications for the government's ability to realize other good governance indicators, such as participatory. To realize the participatory principle, the government must first manifest transparency properly. So that transparency is a strategic aspect to realize good governance in public services.

At the Makassar City Population and Civil Registry Office, transparency of information regarding service requirements has been announced openly, information on service requirements is posted on the office wall in front of the waiting chair before the entrance to the Makassar City Population and Civil Registry Office, so that the public has been given access to information regarding what requirements must be met. However, not all service information is contained on the bulletin board, the standard operating procedure, abbreviated as SOP, has not been opened in a transparent manner so that the public does not know the existing service flow, what is posted on the bulletin board is only the requirements for file completeness, while service procedures are not informed. Of the 15 community researchers interviewed, there were 10 people who said they did not know and did not know where to access information about service procedures, only 5 people said they knew information on service procedures Interview with 15 Communities, how could people access services without knowing the flow services, especially the Office of Population and Civil Registry of Makassar City has made changes to service patterns from offline to online services.

Information on online service procedures must be disseminated so that the public knows the service flow to access services at the Office of Population and Civil Registry of Makassar City. The shift of offline services to online services requires the public to adapt to the new system, besides that the Civil Registry Service must prepare facilities and infrastructure such as computers and internet networks to accommodate people who do not have the means to access files online (West, 2005; Cenfetelli et al., 2008; Tsiotsou et al., 2016). 
Service officers of the Office of Population and Civil Registry of Makassar City have not been responsive in serving online files, people have complained about the lack of clarity of service due to the lack of responsiveness of service officers in providing feedback on files sent online, whether the files meet the requirements or not, the community who uploaded the files that were sent online does not meet the requirements no response is given regarding the rejection of the submitted files, so the public waits without clarity.

Another indicator of transparency is related to the disclosure of information on service costs, the office of the Makassar City Population and Civil Registry Office has provided information on the bulletin board that all services are provided free of charge, but in practice there are many unscrupulous service officers who charge illegal fees. Lack of commitment of service personnel in serving plus the desire of the community to get efficient and clear time services encourages people to pay to get service certainty. Whereas the service fee based on the Regional Regulation of Makassar City Number 9 of 2009 Article 44 has been released or free.

So broadly speaking, based on the results of the above research, it can be concluded that the Makassar City Population and Civil Registry Office has implemented the principle of transparency in providing services but transparency has not been optimal due to the lack of SOP information and the socialization of online services to the public.

\section{Application of the Principle of Participation in Public Services}

In realizing the principle of participation in good governance, the government is required to be open to providing opportunities for the community to take part in improving service quality, therefore the government must make it easy for the public to access information and provide input or suggestions for policy improvements.

Strikingly, participation in public services is measured through a number of indicators such as the existence of a forum to accommodate community participation, both direct and indirect meeting forums, increased quantity and quality of input, criticism and suggestions, public voting rights are used to express opinions, speak out in the process public policy formulation, either directly or indirectly.

Good participation does not only involve groups that have direct interests such as the community, NGOs (Non-Governmental Organizations), parties, the private sector, and members of the DPRD (Regional People's Representative Council) to provide input regarding service policies but more importantly the awareness of the parties. implementing services to involve the community in the formulation of policies that will have an impact on the wider community.

The demand for encouraging participation is not only seeking the participation of the community and other parties in terms of formulating various matters relating to the types of services they need, the best way to provide services, and the service process mechanism, but what is no less important is community involvement in evaluating services, not infrequently in running the service process, many things make it difficult for the community as the subject of service, so that policies that are currently running and are deemed ineffective require new adjustments to be improved. Therefore, participation is needed in two ways, namely in formulating policies and in evaluating public service policies.

\section{Participation in Policy Formulation or Planning}

In policy planning, the Makassar City Population and Civil Registry Office has not involved the community in providing ideas or ideas related to policies to be carried out, the camat coordination meeting, as a medium for the meeting referred to by the head of population 
administration information management in interviews only once a year, namely when the government prepares the regional development budget, the issues discussed in the sub-district coordination meeting are not related to matters relating to services at the Makassar City Population and Civil Registry Office so that service policy planning such as socialization of service procedures, related regulations is made free of all service costs, and problems or service complaints that have occurred so far at the Makassar City Population and Civil Registry Office cannot be handled in the head of the district coordination meeting forum.

It can be concluded that community participation in the formulation or planning of service policies at the Office of Population and Civil Registry of Makassar City has not been optimal. Community involvement in service planning, including service mechanisms, can be done in two ways, namely involving formulations by meeting in person, and involving using online media. like the use of social media, they can create communication between the government and the public. Technology that continues to develop can be put to good use, especially that the results of research by many institutions report that the number of social media users such as Facebook, Twitter, Instagram in Indonesia is the second largest in the world, social media is widely used by the public to provide and seek information, and many other government agencies have used social media to open up spaces for participation in the community because of the low cost and easy method. The impact of not being involved in the formulation of policies has made the community less optimal in obtaining information, for example in the new policy of the Makassar City Population and Civil Registry Office which is currently switching to online services.

Of the 15 interviewees, there were 8 people who did not know the new system related to online service flows, and did not know how to access services online, this is where the importance of opening up participation in policy formulation, the Makassar City Population and Civil Registry Service can listen to the opinions of the related community. what needs people need to access online services, facilities and infrastructure that need to be added to suit the needs of each policy.

\section{Participation in evaluating services}

In public service policy, the government must provide a place for the community to negotiate their interests, as well as issues that disturb or make it difficult for them to access good services. The Department of Population and Civil Registry of Makassar City in providing a space for participation so that the community provides input on their needs has provided several different means of participation, namely complaint booths, suggestion boxes, websites, and whatshap complaints. However, the complaint booth and suggestion box are inside the office, while the procedure for entering the office must first obtain an online queue number, so that only those who get the queue number can enter to access face-to-face services with officers and access the complaint booth. Meanwhile, online queues are limited to 250 people per day, while the public's need for services reaches 1,000 per day. As for the whatshapp number that has been provided by the Makassar City Population and Civil Registry Service, out of 15 people, only 3 know that the Makassar City Population and Civil Registry Service provides a complaint whatshapp. And of the 15 people who interviewed researchers, 12 people answered that they did not know the means to convey criticism and suggestions to officers at the Makassar City Population and Civil Registry Service even though the means to channel criticism and suggestions had been provided but because they were not placed in a place that could be easily reached by the community so that the facility cannot be used.

Therefore, the Department of Population and Civil Registry of Makassar City needs to improve the quality of its complaint facilities, so that they can be accessed easily by the 
public. Complaint facilities are very important to open public participation. With public participation, it is possible for the quality of policies produced by the government, and an increase in the quality felt by the community because it is based on the demand of the community itself. This is of course very beneficial for the community as the target of policy implementation.

Another indicator that can be used to see the level of community participation in public services at the Makassar City Population and Civil Registry Office is whether the Makassar City Population and Civil Registry Office provides feedback on existing compalin.

From the results of research on the non-strategic location or means of complaints, it can be concluded that community participation through the means provided by the Makassar City Population and Civil Registry Service is not widely accessed by the community, so that feedback on complaints cannot be known because of all the interviewees. , said that he never complained directly or indirectly to service officers.

Regarding public complaints, from the observations of researchers, many public complaints are addressed on google search, because the Makassar City Population and Civil Registry Service is not active on social media, so people express complaints through google search reviews. There are 56 reviews related to services at the population and civil registration office of Makassar city on Google search, 32 complaints related to KTP (ID CARD), 14 reviews related to systems, 12 reviews related to management, 11 reviews related to E KTP, 10 reviews related to taking, 8 reviews related to family cards, 7 reviews related data, 5 reviews related to needs.

Of all the existing reviews, not one single review can be given feedback by the Makassar City Population and Civil Registry Service, because even though the complaint was directed to the Makassar City Population and Civil Registry Office, service officers were unable to respond to the reviews provided by the community.

From the comments of the community above which were addressed to the Population and Civil Registry Office of Makassar City, of course the community addressed the complaint to be responded to or seen by the Makassar City Population and Civil Registry Office to become an evaluation material for the Makassar City Population and Civil Registry Office but because it was not addressed. on the website or on social media managed by the Makassar City Population and Civil Registry Service, these complaints cannot be evaluated by the Makassar City Population and Civil Registry Service.

From the results of the above research, it can be concluded that the application of the principle of participation in evaluating public services at the Makassar City Population and Civil Registry Office has been implemented but has not been optimal because the means of participation provided by the Makassar City Population and Civil Registry Service are not placed in a strategic and easy place. Accessed by the entire community, and the lack of socialization to the community regarding the communication media provided by the Makassar City Population and Civil Registry Office to be used to channel criticism of suggestions and questions, and the absence of social media facilities for the Makassar City Population and Civil Registry Service that can be accessed by the public in communicating on social media.

\section{Conclusion}

The application of the principles of transparency and participation in public services at the Population and Civil Registry Office of Makassar City has not been implemented in accordance with the provisions of the regulations because the public service dissemination 
factor has not been understood by the public, participation has not been optimal because complaint management has not been placed in a place that can be easily accessed by the community. The implementation of the principles of good government in public services at the Office of Population and Civil Registry of Makassar City, especially the Principles of Transparency and Participation, should be implemented with a transparent procedure, the public is given easy access to complaints, free service fees in accordance with regulations The population and civil registry office of Makassar City should provide SOP information on information boards in the office, through websites, brochures, and cooperate with village officials, heads of RT (Neighborhood Association) and RW (Citizens Association) to socialize directly to the community.

\section{References}

Ilmar, A. S. H. M. H. (2014). Hukum tata pemerintahan. Prenada Media.

Borah, S. K. (2013). Right to information act: A key to good governance. International Journal of Humanities and Social Science Invention, 2(2), 11-22.

Cenfetelli, R. T., Benbasat, I., \& Al-Natour, S. (2008). Addressing the what and how of online services: Positioning supporting-services functionality and service quality for business-to-consumer success. Information systems research, 19(2), 161-181.

Dwiyanto, A. (2008). Mewujudkan Good Governance Melalui Pelayanan Publik, Yogyakarta: Gajahmada University Press.

Ladwig, B., Rudolf, B., Risse, T., \& Lehmkuhl, U. (2011). International legal and moral standards of good governance in fragile states. Governance Without a State: Policies and Politics in Areas of Limited Statehood. New York: Colombia University Press.

Novianti, L. (2015) Public Sector Governance Pada Pemerintah Daerah, Pekanbaru Riau: LPPM Uin Suska, h. 16.

Sulaiman, A.A, Hendriyadi, A. et al., (2018), Pelayanan Publik Transparan, Efisien dan Kredibel, Jakarta: IAARD Press

Tsiotsou, R. H., Kandampully, J., \& Duddy, R. (2016). The social aspects of consumption as predictors of consumer loyalty: Online vs. offline services. Journal of Service Management.

Bovaird, T., \& Löffler, E. (2003). Evaluating the quality of public governance: indicators, models and methodologies. International review of administrative sciences, 69(3), 313-328.

West, D. M. (2005). Digital government: Technology and public sector performance. Princeton University Press. 